\title{
The Adaptability of Six Introduced Shorea spp. to the Community Forest in Sleman, Yogyakarta
}

\author{
Sapto Indrioko ${ }^{1, *}$ Widiyatno $^{1}$ Birowo Aji Wicaksono $^{1}$
}

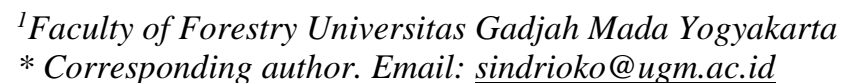

\begin{abstract}
Dipterocarp species dominated tropical rain forests in Kalimantan. Shorea is one of the genera with the highest number of species. It supported the diversity of characters between species, including the possibility to develop outside their natural habitat as exotic species. The prospect of developing Shorea spp. plantations to produce meranti wood in Java is essential because the large market share of wood should come from sustainably managed plantations. Therefore, this research was carried out to evaluate the adaptability of six introduced Shorea spp., especially in the new habitats of Cangkringan area, Sleman, Yogyakarta. The study was carried out in two sites. The first site was in a slightly open area under Falcataria moluccana stands with Kalanjana grass (Brachiaria mutica), while another site was in a more sheltered garden by a denser canopy. Plantation trial on the first site was planted in February 2017, while the second site was planted in March 2018 due to limited seedlings stock and planting site. The plantations were established using a randomized complete block design, consisting of six species, namely Shorea leprosula, S. selanica, S. johorensis, S. platyclados, S. dasyphylla, and S. parvifolia. The research resulted in the best survival of $S$. leprosula in garden areas (100\%), while $S$. selanica well adapted (80\%) in the more open site. The best initial growth is achieved by $S$. leprosula with shade conditions. This result explained that habitat suitability was essential to establish exotic species.
\end{abstract}

Keywords: growth, meranti, exotic species, introduction

\section{INTRODUCTION}

Dipterocarpaceae is a family of trees that grows predominantly in humid tropical forests in Indonesia. It has the most diversity in Kalimantan, namely nine genera, and 267 species [1], 155 species of which are endemic [2]. Shorea is one of the genera within Dipterocarpaceae with the largest number of species. It usually lives in tropical climates with an average annual rainfall of more than $1,000 \mathrm{~mm}$ and dry months less than six months a year [3]. They are found below an altitude of 1,000 $\mathrm{m}$ above sea level, usually living in lowlands with yellow or red soil, deep solum, and well drainage [4]. Based on the timber color, Shorea or Meranti is grouped into red meranti, yellow meranti, white meranti, and balau [5]. Some tested Shorea plantation in Kalimantan are proven to have high survival and known as fastgrowing meranti, e.g., S. platyclados, S. leprosula, S. johorensis, and S. parvifolia [6]. They also have high economic value of timber products.

Shorea can survive under shade circumstances because it has a gap-opportunist character [3]. In the seedling phase, Shorea requires shade, but it will need higher light intensity for growth when it enters the next stage [7]. Due to these characteristics, Shorea presumably can be used as an alternative for enrichment planting in community forests in Java to increase forest productivity and timber value in the future. Farmer groups at Cangkringan, Sleman, are very interested in trying to plant Shorea. However, species' suitability to a particular site is a prerequisite to developing the plantation as a competitive, efficient, and sustainable forest. Therefore, this research was carried out to evaluate the survival and early growth of six exotic Shorea species in the new habitat within community forest areas in Sleman, Yogyakarta. 


\section{MATERIALS AND METHODS}

We conducted the research into two planting times, due to the limited seedling stocks and planting area. The first phase planting was carried out in February 2017, while the second phase was planting in March 2018. The species trial plantations located in the community forest, Cangkringan Area, Sleman Yogyakarta. The geographical location is $7^{\circ} 36^{\prime} 50.23$ 'S and $110^{\circ} 27^{\prime} 03.15^{\prime \prime} \mathrm{E}$. It is located at $757 \mathrm{~m}$ above sea level. They were established using Randomized Complete Block Design (RCBD), consisted of six species, namely Shorea dasyphylla, S. johorensis, $S$. leprosula, $S$. parvifolia, $S$. platyclados, and $S$. selanica. Each species consisted of three tree plots and planted with a spacing of $4 \mathrm{~m} \mathrm{x}$ $4 \mathrm{~m}$. We set up the first phase with replications of 14 blocks, established within the $6 \mathrm{~m} \times 6 \mathrm{~m}$ spacing of the Falcataria moluccana stand. The community also uses this site to plant Kalanjana grass, which is harvested periodically. The second phase comprised four blocks as replication. There are several grown plants that cover the planted Shorea seedlings, e.g. Artocarpus altilis, A. heterophyllus, Swietenia macrophylla, Gnetum gnemon, Cocos nucifera, and Syzygium polyanthum. The second site showed denser trees and more shade in comparison with the first site.

S. selanica seedlings were cultivated using collected seed originated from parent trees surrounding Universitas Gadjah Mada campus in Yogyakarta. While S. dasyphylla, S. johorensis, $S$. leprosula, $S$. parvifolia, and $S$. platyclados propagules were collected as wildings originated from a forest concession area of P.T. Sari Bumi Kusuma, Nanga Nuak, Central Kalimantan. Observations of survival, health, height, and plant diameter of each individual were carried out in May 2019. Data for both plantations were analyzed using analysis of variance to determine the effect of species. If there is a significant difference, we proceed with the Duncan Multiple Range Test (DMRT) to locate the significant difference among species.

\section{RESULT AND DISCUSSION}

\subsection{Survival Rate}

In general, Shorea planted in garden areas showed a better survival rate $(47 \%$, Figure 1$)$ than under $F$. moluccana stands (25\%, Figure 2). The survival of Shorea seedlings under $F$. moluccana stands decreased by more than half compared to a year previously observed [8]. S. leprosula adapted best (all seedlings survived) in garden areas (Figure 1) but survived only one-fifth if planted in a more open space (Figure 2). All species tested (except $S$. selanica) showed better adaptability in the garden with more shade than under the $F$. moluccana stand. Species tests carried out in the natural distribution locations in Central Kalimantan also showed that $S$. leprosula had the highest survival (85\%) observed until the plant was 12.5 years old [9]. In comparison, the test of 20 local Shorea species in West Kalimantan showed an average survival rate of $82.5 \%$ [10].

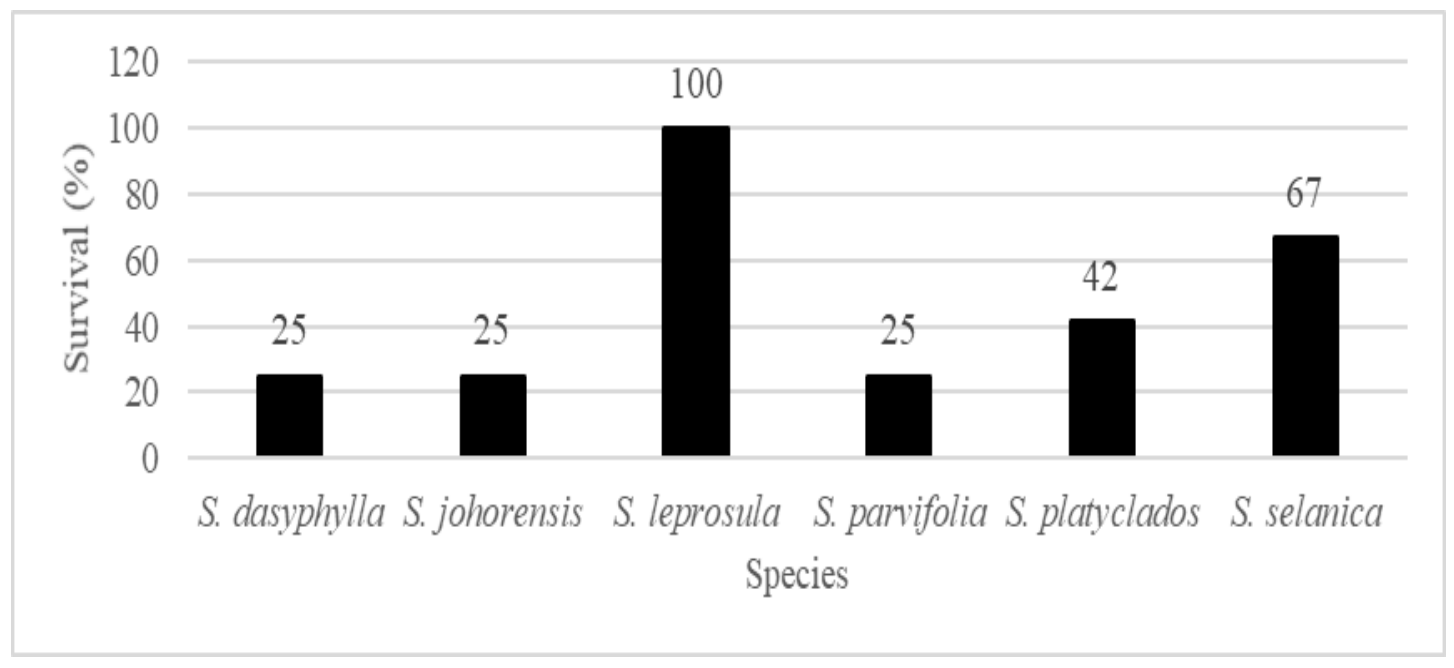

Figure 1. Survival rate of six exotic Shorea species planted in the garden 
The high survival rate is natural, considering that native Shorea has undoubtedly adapted well to the site and the climate conditions in their natural distribution. The research location in Cangkringan area, Sleman has different climatic conditions with lower average rainfall, namely $2,500 \mathrm{~mm} /$ year [11]. Meanwhile, the rainfall at the location of the Dipterocarpaceae in Central Kalimantan is around 3,000 mm/year [12]. It suggests that Dipterocarp species naturally thrive in locations where rainfall is more or less evenly throughout the year. Even though the Cangkringan area, Sleman, has sufficient annual rainfall, there are still dry months, especially in the dry season, causing plant stress due to lack of water and reducing physiological processes' ability and even cause death. Water is essential for plants because the physiological processes that take place in plants are related to the presence of water and materials dissolved in water [13].

S. selanica could survive ( $80 \%$, Figure 2$)$ better in more open sites than in more closed places $(67 \%$, Figure 1). It indicates that each species has specific site suitability to survive well. This species originated from the central part of the Moluccas, confined to Ambon, Buru, Obi, Seram, and Sula islands [14], with an average annual rainfall of less than 2,500 $\mathrm{mm} /$ year [15]. The present research location is likely to have environmental conditions, especially annual rainfall, similar to natural distribution. Furthermore, $S$. selanica grows well under limited shade trees [16] that support more adaptability to the lower site humidity.

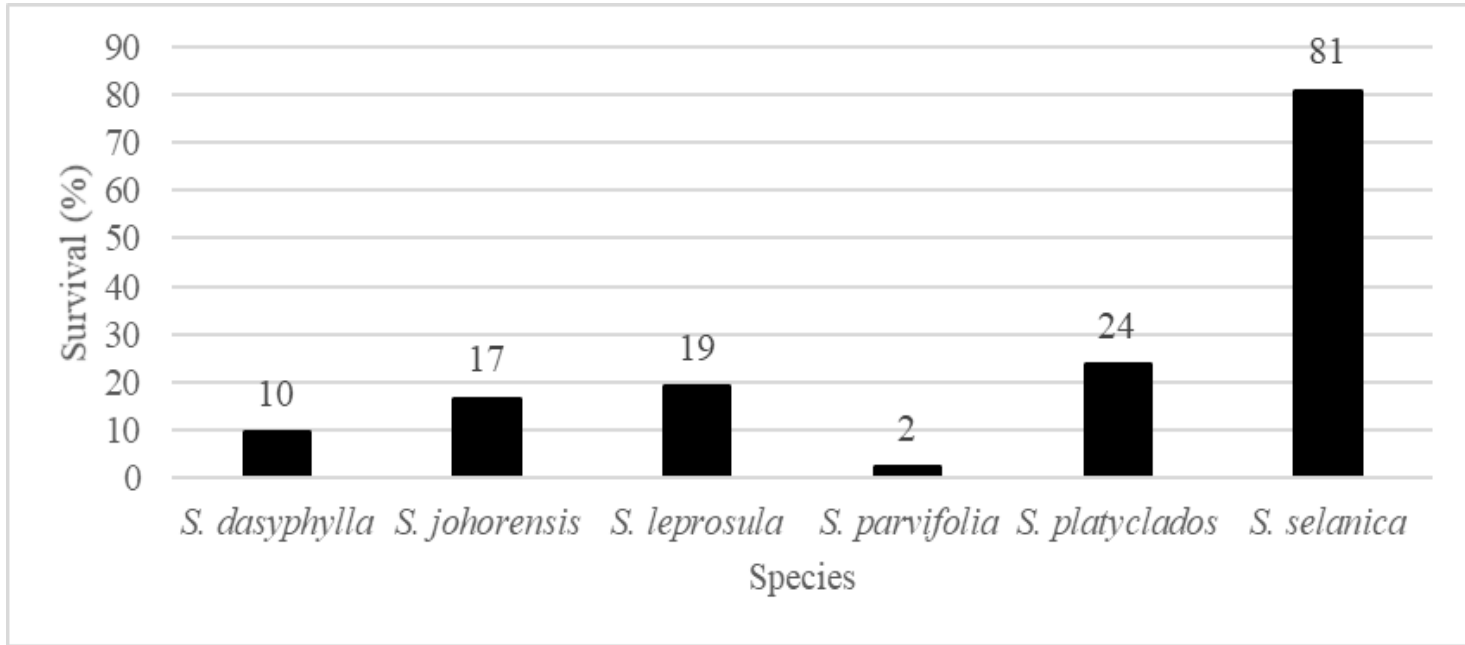

Figure 2. Survival rate of six exotic Shorea species planted under F. moluccana stand

\subsection{Initial Growth Rate}

Analysis of variance could not be carried out for trial under $F$. moluccana stand due to very low of survival rate $(25 \%)$. The results of the analysis of variance of species tested in the garden site showed significant differences in height and diameter growth among species (Table 1). S. leprosula had the best increase in height and diameter (Tables 2 and 3). The initial growth observed in the 6.5-year-old Dipterocaps species test in Central Kalimantan also showed that $S$. leprosula had the best increase in height and diameter [6]. Shorea dasyphylla, S. johorensis, $S$. leprosula, $S$. parvifolia, and $S$. platyclados belong to red meranti [5]. Too intense sunlight would induce water-deficient, and red meranti seedlings frequently suffer from drought [3]. The suitable sunlight is very important to give an optimum environment for supporting tree growth. Therefore, canopy density management above the enrichment planted of Shorea and other Dipterocarps [17] is essential, even they are established as a secondary forest within its natural distribution. The appropriate enrichment planting achievement will increase forest productivity [18] and maintain genetic diversity [19].

The exotic Shorea spp. have been introduced mainly to surrounding West Java since 1938 [20]. The addition of species and planting area continued until three species, i.e., S. leprosula, S. selanica, and $S$. platyclados reached the domestication stage. Forest state enterprise of Perhutani developed as commercial stands in the Forest Management Unit of Bogor and Banten [20]. It indicated that these exotic species have the best adaptability to West Java. 
Table 1. Analysis of variance of species test planted in the garden

\begin{tabular}{lccccc}
\hline \multirow{2}{*}{ Source } & df & \multicolumn{2}{c}{ Mean Square } & \multicolumn{2}{c}{ F Value } \\
\cline { 2 - 6 } & & Diameter & Height & Diameter & Height \\
\hline Block & 3 & 0.081 & 1676.916 & $3.33^{\mathrm{ns}}$ & $3.01^{\mathrm{ns}}$ \\
Species & 5 & 0.313 & 7288.912 & $12.93^{* *}$ & $13.09^{* *}$ \\
\hline Note: ${ }^{* *}=$ significant at $p \leq 0.01 ;$ ns=not significant
\end{tabular}

Table 2. DMRT results of species test planted in the garden

\begin{tabular}{lcccc}
\hline \multicolumn{1}{c}{ Species } & \multicolumn{2}{c}{ Diameter $(\mathbf{c m})$} & \multicolumn{2}{c}{ Height $(\mathbf{c m})$} \\
\hline S. leprosula & 0.98 & $\mathrm{a}$ & 129.17 & $\mathrm{a}$ \\
S. selanica & 0.98 & $\mathrm{a}$ & 89.50 & $\mathrm{~b}$ \\
S. platyclados & 0.68 & $\mathrm{~b}$ & 77.20 & $\mathrm{bc}$ \\
S. dasyphylla & 0.52 & $\mathrm{~b}$ & 52.00 & $\mathrm{c}$ \\
S. parvifolia & 0.50 & $\mathrm{~b}$ & 50.67 & $\mathrm{c}$ \\
S. johorensis & 0.46 & $\mathrm{~b}$ & 47.75 & $\mathrm{c}$ \\
\hline
\end{tabular}

This fact is in line with the present results, $S$. leprosula, S. selanica, and $S$. platyclados are the best three species in terms of survival and diameter and height growth.

As all $S$. dasyphylla, $S$. johorensis, S. leprosula, $S$. parvifolia, and $S$. platyclados seedlings were transferred directly from Central Kalimantan, they need some time to adjust to the local climate and site of the species test. Seedling roots did not respond quickly to grow and consume sufficient water to compensate for transpiratory water losses [21]. In contrast, $S$. selanica seeds were collected from the parent trees in Yogyakarta. This parent tree generation has successfully passed natural selection. They already adapted to the local environment during the establishment as ornamental trees on the roadside of the UGM campus in Yogyakarta until they grew and reproduced regularly. Therefore, S. selanica has a much better survival ability than the others on a more open site.

S. selanica and $S$. leprosula are promising for further research on their adaptability and growth in community forests in Sleman, Yogyakarta. Growth monitoring until the harvesting age is required to determine the productivity of these species. If we develop them, selecting an appropriate site is essential to grow optimally and produce high-value alternative timber for the community.

\section{CONCLUSION}

Site use cannot be generalized to all Shorea species. It should be adjusted to the characters of each species. Precipitation is essential for supporting the plant survival. Furthermore, differences in shade can cause variations in adaptation and growth. Based on the early evaluation, two out of six Shorea species are promising for further research on their adaptability and growth in community forests in Cangkringan area, Sleman, Yogyakarta. S. leprosula well adapted to shade garden, while $S$. selanica adapted to more light under $F$. moluccana stand.

\section{ACKNOWLEDGMENTS}

We sincerely thank Mr. Susilo Purnomo, P.T. Sari Bumi Kusuma, Nanga Nuak, Central Kalimantan, for providing the wildlings to this research.

\section{REFERENCES}

[1] U. Hairah, A. Tejawati, E. Budiman, F. Agus, Borneo biodiversity: exploring endemic tree species and wood characteristics, in: L.S. Riza, A. Pranolo, A.P. Wibawa, E. Junaeti, Y. Wihardi, U.R. Hashim, S.J. Horng, R. Drezewski, H.S. Lim, G. Chakraborty, L. Hernandez, S. Nazir (Eds.), Proceeding of the 3rd International Conference on Science in Information Technology (ICSITech), IEEE, 2017, pp. 435-440, DOI: https://doi.org/10.1109/ICSITech.2017.8257152

[2] M.A. Khan, R.A. Spicer, T.E.V. Spicer, S. Bera, Occurrence of Shorea Roxburgh ex C. F. Gaertner (Dipterocarpaceae) in the Neogene Siwalik Forests of Eastern Himalaya and its biogeography during the cenozoic of southeast asia, Review of Palaeobotany and Palynology 233 (2016) 236-254. DOI: https://doi.org/10.1016/j.revpalbo.2016.07.011.

[3] J. Ghazoul, Dipterocarp biology, ecology, and conservation, Oxford University Press, Oxford, 2016.

[4] Purwaningsih, E. Kintamani, The diversity of Shorea spp. (meranti) at some habitats in Indonesia, in: Miftahudin, B. Juliandi, W. Priawandiputra, M. Muttaqin (Eds.), Proceeding of the 2nd International Conference on Biosciences (ICoBio), IOP Conference Series: Earth and Environmental Science, vol. 197, 2018, 012034, pp. 1-10. DOI: https://doi.org/10.1088/17551315/197/1/012034

[5] Y. Tsumura, T. Kado, K. Yoshida, H. Abe, M. Ohtani, Y. Taguchi, Y. Fukue, N. Tani, S. Ueno, K. Yoshimura, K. Kamiya, K. Harada, Y. Takeuchi, B. Diway, R. Finkeldey, M. Na'iem, S. Indrioko, K.K.S. Ng, N. Muhammad, S.L. Lee, Molecular database for classifying Shorea species (Dipterocarpaceae) and techniques for 
checking the legitimacy of timber and wood products, Journal of Plant Research 124 (2011) 35-48, DOI: https://doi.org/10.1007/s10265010-0348-z.

[6] Widiyatno, Soekotjo, M. Naiem, S. Purnomo, P.E. Setiyanto, Early performance of 23 dipterocarp species planted in logged-over rainforest, Journal of Tropical Forest Science 26(2) (2014) 259-266.

[7] H.H. Rachmat, P. Pamoengkas, L. Sholihah, R.A. Fambayun, A. Susilowati, The effect of planting technique on the growth of two Shorea Species in Gunung Dahu, Bogor, Indonesia, Biodiversitas 21(9) (2020) 4131-4138, DOI: https://doi.org/10.13057/biodiv/d210926.

[8] B.A. Wicaksono, Evaluasi awal pertanaman uji spesies Meranti di Bawah Tegakan Sengon di Desa Kepuharjo, Kecamatan Cangkringan, Kabupaten Sleman, Undergraduate Thesis, Fakultas Kehutanan Universitas Gadjah Mada, Yogyakarta, 2018. [In Bahasa Indonesia]

[9] Widiyatno, F. Hidayati, S. Hardiwinoto, S. Indrioko, S. Purnomo, Jatmoko, N. Tani, M. Naiem, Selection of dipterocarp species for enrichment planting in a secondary tropical rainforest, Forest Science and Technology 16(4) (2020) 206-215, DOI: https://doi.org/10.1080/21580103.2020.183162 $\underline{0}$.

[10] P. Gunawan, A. Muin, R.S. Wulandari, Uji spesies (Shorea spp.) di IUPHHK-HA PT. Suka Jaya Makmur Kabupaten Ketapang, Jurnal Hutan Lestari 4(4) (2016) 543-551. [In Bahasa Indonesia]

[11] Pemerintah Desa Kepuharjo, Letak dan Luas Wilayah [Internet], 2020, Available from: https://kepuharjo.slemankab.go.id/. [In Bahasa Indonesia]

[12] BPS Melawi, Jumlah curah hujan dan hari hujan bulanan di stasiun meteorologi Nanga Pinoh tahun 2014 [Internet], 2015, Available from:

https://melawikab.bps.go.id/statictable/2015/11/ 05/31/jumlah-curah-hujan-dan-hari-hujanbulanan-di-stasiun-meteorologi-nanga-pinohtahun-2014.html. [In Bahasa Indonesia]

[13] J.D. Scharwies, J.R. Dinneny, Water transport, perception, and response in plants, Journal of Plant Research 132 (2019) 311-324, DOI: https://doi.org/10.1007/s10265-019-01089-8.

[14] H.H. Rachmat, K. Kamiya, K. Harada, Contrasting cpDNA variation in two indonesian endemic lowland dipterocarp species and implications for their conservation, Pakistan Journal of Biological Sciences 15(6) (2012) 783-788, DOI: https://doi.org/10.3923/pjbs.2012.783.788.

[15] BPS Maluku, Jumlah curah hujan bulanan di stasiun meteorologi Kairatu, Amahai, Geser, Namlea, dan Dobo tahun 2016 [Internet], 2017, Available from: https://maluku.bps.go.id/subject/157/iklim.html \#subjekViewTab3.html. [In Bahasa Indonesia]

[16] R.D. Maripa, R.D. David, N.H. Daud, Response of Shorea species to drought stress, in: L.K. Chiang (Ed.), prospects and utilization of tropical plantation trees, CRC Press, Boca Raton, 2020, pp. 157-178. DOI: https://doi.org/10.1201/9780429442773.

[17] J. Millet, N. Tran, N.V. Ngoc, T.T. Thi, D. Prat, Enrichment planting of native species for biodiversity conservation in a logged tree plantation in Vietnam, New Forests 44 (2013) 369-383, DOI: https://doi.org/10.1007/s11056012-9344-6.

[18] Widiyatno, S. Purnomo, Soekotjo, M. Na'iem, S. Hardiwinoto, Kasmujiono, The growth of selected Shorea spp. in Secondary tropical rain forest: the effect of silviculture treatment to improve growth quality of Shorea spp., Procedia Environmental Sciences, 7 (2013) 160-166, DOI: https://doi.org/10.1016/j.proenv.2013.02.024.

[19] Widiyatno, S. Indrioko, M. Na'iem, K. Uchiyama, S. Numata, M. Ohtani, A. Matsumoto, Y. Tsumura, Effects of different silvicultural systems on the genetic diversity of Shorea parvifolia populations in the tropical rainforest of Southeast Asia, Tree Genetics \& Genomes 12(73) (2016) 1-12, DOI: https://doi.org/10.1007/s11295-016-1030-y.

[20] H. Alrasyid, Sejarah dan pengalaman pembuatan tegakan Dipterocarpaceae di Jawa, in: E.B. Hardiyanto (Ed.), Prosiding Seminar Nasional Status Silvikultur Indonesia 1999, Fakultas Kehutanan Universitas Gadjah Mada, Yogyakarta, 2000, pp. 87-92. [In Bahasa Indonesia]

[21] Y. Osakabe, A. Kawaoka, N. Nishikubo, K. Osakabe, Responses to environmental stresses in woody plants: key to survive and longevity, Journal of Plant Research, 125 (2012) 1-10, DOI: https://doi.org/10.1007/s10265-011-04466. 